\title{
ANALYSIS OF OPTICAL DENSITY OF REGENERATE IN THE AUTOMATIC LOWER LEG LENGTHENING CONDITIONS WITH INCREASED RATE AT DIFFERENT METHODS OF BONE CONTINUITY
}

\author{
Gorbach E.N. ${ }^{1}$, Gorbach E.S. ${ }^{2}$, Kononovich N.A. ${ }^{1}$, Popkov A.V. ${ }^{1}$

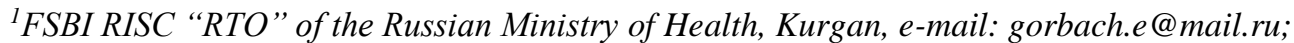 \\ ${ }^{2}$ FSBEI HE South Ural State Medical University Academy of the Russian Ministry of Health, Chelyabinsk
}

Aims.

The work was aimed at the investigation of the diagnostic value of analysis of the optical density of bone regenerate under conditions of accelerated automatic lengthening of the lower leg.

Materials and methods.

A comparative analysis of the optical density (on the digitised X-ray images) of different areas of distraction regenerates of the tibia in 14 adult mongrel dogs aged 1 to 3 years at the stages of automatic lengthening of the lower leg with the Ilizarov technique, at a rate of $3 \mathrm{~mm}$ per day with preliminary bone damage by flexion osteoclasis (series I) and oblique osteotomy (series II).

Results.

The study revealed that the method of bone continuity by oblique osteotomy promotes more active osteogenesis in the distraction period and the support ability of the extremity within 14 days after dismantling the apparatus, which reduces the apparatus period by $16 \%$ compared with the series for which flexion osteoclasis was used. At the same time, signs of incomplete organotypic rearrangement of the newly formed diaphysis area, especially pronounced in series II, persist after 30 days of the apparatus-free period.

Conclusions.

When the optical density values of the distraction regenerate in intermediary and endosteal regions with two or more surfaces are more than 0.5 conditional units, and in the rest - not less than 0.33 conditional units, the onset of regenerate support ability was noted in both series. The resulting values can be criteria for dismantling the apparatus.

Keywords: flexion osteoclasis, oblique osteotomy, transosseus distraction osteosynthesis, autodistractor, tibia, regenerate, optical density.

\section{INTRODUCTION.}

The reduction of the duration of external fixation for the lengthening of a limb by the method of distraction osteosynthesis remains one of the acute issues in modern traumatology and orthopedics. One of the solutions to this problem is an increase in the daily rate of distraction. It is known that the lengthening of a lower leg with a distraction rate of $3 \mathrm{~mm}$ in a high-divisional mode can reduce the time of external fixation to 30\% [1]. Intramedullary elastic reinforcement contributes to the reduction of the period of fixation to 2 weeks [2]. However, in some cases, this method requires repeated surgical intervention for the removal of the reinforcing elements. For the correction of the bone deformity and lengthening of limbs, some authors use oblique osteotomy [3].

Such technique contributes to the faster replacement of diastasis with bone tissue in patients treated for the deformities of long bones and during lengthening of limbs [4-6]. The main method of controlling of the regenerative process of the lengthening limb is multiple $\mathrm{X}$-ray imaging during the treatment [7]. Recently, orthopedists-traumatologists have received a possibility to obtain additional data using qualitative analysis of digital X-ray images [8].

The density of the regenerate depends on the degree of its mineralization. One of the objective criteria of the evaluation of the bone tissue condition is optical density. It is the most important diagnostic sign that allows the specialists to make a prognosis on the disease development 
and control the treatment efficiency [9].

The study was aimed to perform a comparative analysis of optical density in digital X-ray images of distraction regenerates at different stages of the automatic distraction of a lower leg with the rate of distraction of $3 \mathrm{~mm} /$ day.

\section{MATERIALS AND METHODS.}

The study included 14 adult outbred dogs aged 1-3 years old with bodyweight from $24 \pm 3.1 \mathrm{~kg}$, the mean length of the lower leg was $18.6 \pm 1.3 \mathrm{~cm}$. The dogs had their lower leg fixed with an Ilizarov apparatus and the bone was damaged. In Series I of tests, the bone was damaged by flexion osteoclasis in the mid-third, in Series II of tests - by oblique osteotomy. For the next 10 days, the lengthening of the lower leg was performed by the method of automatic transosseous distraction osteosynthesis with a $3-\mathrm{mm}$ distraction rate and 120-fold division. The limb lengthened by $15.7 \pm 1.3 \%$.

Experiments on animals were conducted according to the "European Convention for the Protection of Vertebrate Animals Used for Experimental and other Scientific Purposes"(Strasburg, March 18, 1986), ETS N 123 and the Decree of the Ministry of the Russian Federation No. 199N "Good Laboratory Practice" dated April 1, 2016.

The study on the evaluation of optical density was performed using digitalized X-ray images taken 10 days after the distraction, after the removal of the external fixation (Series I - 30 days, Series II - 15 days), and 30 days after the removal of the external fixation.

X-ray images of the operated lower legs were taken in the frontal and lateral projections using the X-ray apparatus "VEP X Technology Premium VET" (Spain). The X-ray images were digitalized by their scanning with "HP Scanjet 7400c" (Hewlett Packard, California) and saved on the computer.

The intensity (Ii) of shadows of different parts of the regenerate was evaluated by the HiScene software intended for reading and computed processing of the results of X-ray studies [10]. The evaluation of Ii at the stage of distraction was performed in the periosteal, endosteal, and intermediary areas of the regenerate with the anterior, posterior, and lateral surfaces of the proximal and distal fractured bone fragments, proximal and distal bone sections, and the area of the connective tissue extension (Figure 1). During the next stages of the experiment, the intensity of shadows was evaluated in the analog projections of the regenerate areas. Further, optical density was calculated by the formula ODi $=\lg \left((\mathrm{Ii}-\mathrm{Im}) / \mathrm{I}_{0}\right)$, where $\mathrm{Ii}-$ the intensity of the $i$-th element of the image, Im - the mean intensity of soft tissues shadows, $\mathrm{I}_{0}$ - the mean intensity of the background. The statistical processing was performed in the Attestat v.1.0 software [11]. The significance of the difference was evaluated by the methods of variance and non-parametric statistics. Depending on the character of the samplings distributions, Wilcoxon's or Student's t-test was used. 


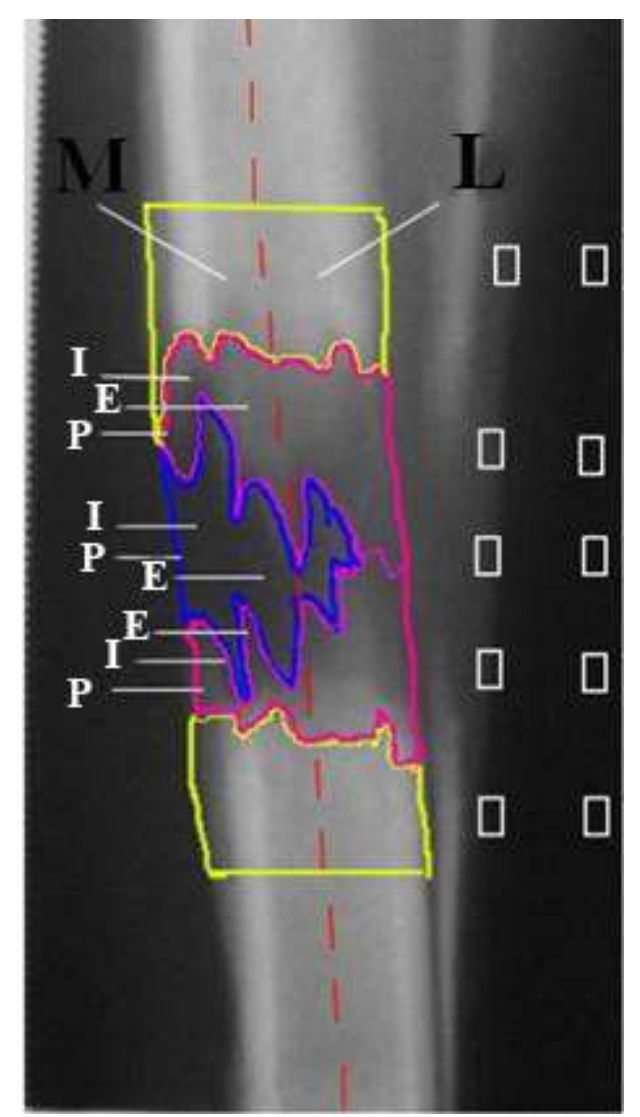

The scheme of the measurement of the optical density of shadows in different areas of the distraction regenerate. $M$-medial surface. $L$-Lateral surface. The yellow contour in the upper part-proximal fractured bone fragment; in the lower part-distal fractured bone fragment. The pink contour in the upper part-proximal bone section, in the lower part-distal bone section.

Blue contour - the area of connective tissue extension.

$P$ - periosteal area of the regenerate. I-intermediary area of the regenerate.

$E$ - endosteal area of the regenerate.

\section{RESULTS.}

It was revealed that 10 days after the distraction, the density in the fractured bone fragments in the animals from Series II decreased in comparison with Series I by 12-18\%, except for the posterior surface wherein it hardly changed (Table 1). In the proximal bone region, the OD values in the medial surface in the endosteal and intermediary areas in the animals from Series II were lower than in Series I by 8 and 20\%, respectively. On the contrary, in the anterior surface, animals after flexion osteoclasis had higher parameters in all the areas by 2.5-3 times and, in the posteriorby 2-3.7 tomes. In the distal bone section, OD values were higher by 1.43 times than the analog parameters in Series I in the lateral intermediary area. In the endosteal and periosteal areas, there were no significant differences revealed.

The analysis of analog areas in the medial surface revealed a decrease in the OD by $8-34 \%$ in comparison with the group of animals after flexion osteoclasis.

Table 1. The optical density in different areas of the distraction regenerate in the tibia 10 days after the 
distraction.

\begin{tabular}{|c|c|c|c|c|c|c|c|c|c|}
\hline \multicolumn{2}{|c|}{ Regenerate areas } & \multicolumn{8}{|c|}{$\mathrm{OD}(\mathrm{M} \pm \mathrm{m})$} \\
\hline & & \multicolumn{8}{|c|}{ Regenerate region (in regards to the studied surface) } \\
\hline & & \multicolumn{2}{|c|}{ Lateral } & \multicolumn{2}{|c|}{ Medial } & \multicolumn{2}{|c|}{ Anterior } & \multicolumn{2}{|c|}{ Posterior } \\
\hline & & I & I & I & I & I & I & I & I \\
\hline \multirow{2}{*}{\multicolumn{2}{|c|}{ Proximal fractured bone fragment }} & $0.76 \pm 0.031$ & $0.66 \pm 0.0220$ & $0.74 \pm 0.032$ & $0.61 \pm 0.021$ & $0.67 \pm 0.030$ & $0.56 \pm 0.019$ & $0.68 \pm 0.024$ & $0.67 \pm 0.027$ \\
\hline & & & $*$ & $*$ & $*$ & $*$ & $*$ & $* * *$ & $* * *$ \\
\hline \multirow{2}{*}{\multicolumn{2}{|c|}{ Distal fractured bone fragment }} & $0.73 \pm 0.029$ & $0.62 \pm 0.0230$ & $0.74 \pm 0.036$ & $0.60 \pm 0.031$ & $0.61 \pm 0.029$ & $0.61 \pm 0.021$ & $0.60 \pm 0.026$ & $0.64 \pm 0.024$ \\
\hline & & $*$ & $*$ & * & * & $* * *$ & $* * *$ & $* *$ & $* *$ \\
\hline \multirow{6}{*}{$\begin{array}{l}\text { Proximal bone } \\
\text { section }\end{array}$} & Periosteal area & $0.51 \pm 0.017$ & $0.43 \pm 0.0140$ & $0.34 \pm 0.011$ & $0.33 \pm 0.013$ & $0.17 \pm 0.006$ & $0.35 \pm 0.011$ & $0.22 \pm 0.010$ & $0.54 \pm 0.021$ \\
\hline & & & $*$ & $* * *$ & $* * *$ & $*$ & $*$ & $*$ & . \\
\hline & Endosteal area & $0.62 \pm 0.032$ & $0.58 \pm 0.0300$ & $0.54 \pm 0.018$ & $0.50 \pm 0.014$ & $0.28 \pm 0.011$ & $0.43 \pm 0.020$ & $0.29 \pm 0.013$ & $0.58 \pm 0.022$ \\
\hline & & $* *$ & ** & $* *$ & $* *$ & * & * & * & $*$ \\
\hline & Intermediary area & $0.54 \pm 0.019$ & $0.56 \pm 0.017[0$ & $0.64 \pm 0.031$ & $0.45 \pm 0.019$ & $0.16 \pm 0.006$ & $0.56 \pm 0.027$ & $0.16 \pm 0.005$ & $0.59 \pm 0.016$ \\
\hline & & $* *$ & $* *$ & $*$ & $*$ & $*$ & $*$ & $*$ & $*$ \\
\hline \multirow[t]{2}{*}{ Distal bone section } & Periosteal area & $0.36 \pm 0.007$ & $0.36 \pm 0.0040$ & $0.47 \pm 0.016$ & $0.32 \pm 0.012$ & $0.06 \pm-.001$ & $0.45 \pm 0.013$ & $0.30 \pm 0.010$ & $0.39 \pm 0.011$ \\
\hline & & $* * *$ & $* * *$ & & * & 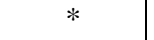 & * & ** & \\
\hline
\end{tabular}




\begin{tabular}{|c|c|c|c|c|c|c|c|c|c|}
\hline & Endosteal area & $\begin{array}{c}0,51 \pm 0,013 \\
* *\end{array}$ & $\begin{array}{c}0,53 \pm 0,011 \\
* *\end{array}$ & $\begin{array}{c}0,48 \pm 0,012 \\
* * *\end{array}$ & \begin{tabular}{|c|}
$0,47 \pm 0,011$ \\
$* * *$
\end{tabular} & $\begin{array}{c}0,16 \pm 0,028 \\
*\end{array}$ & $\begin{array}{c}0,57 \pm 0,020 \\
*\end{array}$ & $\begin{array}{c}0,14 \pm 0,005 \\
*\end{array}$ & $\begin{array}{c}0,49 \pm 0,017 \\
*\end{array}$ \\
\hline & Intermediary area & $\begin{array}{c}0,36 \pm 0,011 \\
*\end{array}$ & $\begin{array}{c}0,50 \pm 0,021 \\
*\end{array}$ & $\begin{array}{c}0,54 \pm 0,018 \\
*\end{array}$ & $\begin{array}{c}0,45 \pm 0,009 \\
*\end{array}$ & $\begin{array}{c}0,05 \pm 0,002 \\
*\end{array}$ & $\begin{array}{c}0,58 \pm 0,025 \\
*\end{array}$ & $\begin{array}{c}0,18 \pm 0,006 \\
*\end{array}$ & $\begin{array}{c}0,57 \pm 0,026 \\
*\end{array}$ \\
\hline \multirow[t]{3}{*}{$\begin{array}{l}\text { Median connective } \\
\text { tissue extension }\end{array}$} & Periosteal area & $\begin{array}{c}0,47 \pm 0,013 \\
*\end{array}$ & $\begin{array}{c}0,37 \pm 0,016 \\
*\end{array}$ & $0 *$ & $\begin{array}{c}0,17 \pm 0,002 \\
*\end{array}$ & $\begin{array}{c}0,01 \pm 0,000 \\
4 *\end{array}$ & $\begin{array}{c}0,35 \pm 0,013 \\
*\end{array}$ & $\begin{array}{c}0,09 \pm 0,002 \\
*\end{array}$ & $\begin{array}{c}0,41 \pm 0,015 \\
*\end{array}$ \\
\hline & Endosteal area & $\begin{array}{c}0,46 \pm 0,021 \\
* * *\end{array}$ & $\begin{array}{c}0,45 \pm 0,020 \\
* * *\end{array}$ & $0,25 \pm 0,01 *$ & $\begin{array}{c}0,47 \pm 0,017 \\
*\end{array}$ & $\begin{array}{c}0,01 \pm 0,000 \\
4 *\end{array}$ & $\begin{array}{c}0,49 \pm 0,019 \\
*\end{array}$ & $\begin{array}{c}0,04 \pm 0,001 \\
*\end{array}$ & $0,57 \pm 0,25^{*}$ \\
\hline & Intermediary area & $\begin{array}{c}0,45 \pm 0,019 \\
* *\end{array}$ & $\begin{array}{c}0,47 \pm 0,021 \\
* *\end{array}$ & $\begin{array}{l}0 \\
*\end{array}$ & $\begin{array}{c}0,35 \pm 0,015 \\
*\end{array}$ & $0 *$ & $\begin{array}{c}0,53 \pm 0,023 \\
*\end{array}$ & $\begin{array}{c}0,14 \pm 0,005 \\
*\end{array}$ & $\begin{array}{c}0,57 \pm 0,021 \\
*\end{array}$ \\
\hline
\end{tabular}

$*_{-}$at $\mathrm{p}<0.01$ - differences are significant in comparison with animals from the other test series;

$* *$ - at $\mathrm{p}<0.05$ - differences are significant in comparison with animals from the other test series;

$* * *$ - at $\mathrm{p} \geq 0.05$ - differences are insignificant in comparison with animals from the other test series.

On the anterior and posterior surfaces, the OD in animals from Series II increased in all the areas by 2-7 times. The minimal parameters of OD in animals from both groups were revealed in the area of median connective tissue extension. On the lateral surface, the parameters in both groups were identical in all the regions of the regenerate. In the rest regions, the parameters in Series II were 1.5-5 times higher than in Series I.

By the end of the period of external fixation, in Series II, a decrease in the OD by 10-23\% was observed in the areas of fractures bone fragments and all the regions of the regenerate on the medial and lateral surfaces (Table 2). In all the other areas on the anterior and posterior surfaces, the differences in the parameters were either insignificant or higher by 1.2-1.4 times than in Series I. The highest increase in the parameters was registered in animals from Series II in the periosteal area.

Table 2. The optical density in different areas of the distraction regenerate in the tibia at the end of the period of fixation

\begin{tabular}{|c|c|c|c|c|c|c|c|c|c|}
\hline \multirow{4}{*}{\multicolumn{2}{|c|}{ Regenerate areas }} & \multicolumn{8}{|c|}{$\mathrm{OD}(\mathrm{M} \pm \mathrm{m})$} \\
\hline & & \multicolumn{8}{|c|}{ Regenerate region (in regards to the studied surface) } \\
\hline & & \multicolumn{2}{|c|}{ Lateral } & \multicolumn{2}{|c|}{ Medial } & \multicolumn{2}{|c|}{ Anterior } & \multicolumn{2}{|c|}{ Posterior } \\
\hline & & I & I & I & I & I & I & I & I \\
\hline \multicolumn{2}{|c|}{ Proximal fractured bone fragment } & $\begin{array}{c}0.62 \pm 0.027 \\
* *+\end{array}$ & $\begin{array}{c}0.58 \pm 0.021 \\
* *+\end{array}$ & $\begin{array}{c}0.63 \pm 0.023 \\
*+\end{array}$ & $\begin{array}{c}0.49 \pm 0.018 \\
*_{+}\end{array}$ & $\begin{array}{c}0.75 \pm 0.031 \\
*+\end{array}$ & $\begin{array}{c}0.61 \pm 0.023 \\
*++\end{array}$ & $\begin{array}{c}0.68 \pm 0.021 \\
* *+++\end{array}$ & $\begin{array}{l}0.65 \pm 0.022 \\
* *+++\end{array}$ \\
\hline \multicolumn{2}{|c|}{ Distal fractured bone fragment } & $\begin{array}{l}0.51 \pm 0.021 \\
*_{+}\end{array}$ & $\begin{array}{l}0.61 \pm 0.029 \\
*_{+}\end{array}$ & $\begin{array}{l}0.60 \pm 0.022 \\
*\end{array}$ & $\begin{array}{l}0.48 \pm 0.021 \\
*_{+}\end{array}$ & $\begin{array}{l}0.72 \pm 0.029 \\
*_{+}\end{array}$ & $\begin{array}{l}0.54 \pm 0.22 \\
*_{+}\end{array}$ & $\begin{array}{l}0.61 \pm 0.021 \\
* * *+++\end{array}$ & $\begin{array}{l}0.63+0.024 \\
* * *+++\end{array}$ \\
\hline \multirow[t]{3}{*}{$\begin{array}{l}\text { Proximal bone } \\
\text { section }\end{array}$} & Periosteal area & $\begin{array}{l}0.40 \pm 0.013 \\
* *_{+}\end{array}$ & $\begin{array}{l}0.31 \pm 0.014 \\
* *+\end{array}$ & $\begin{array}{l}0.32+0.012 \\
*+++\end{array}$ & $\begin{array}{l}0.08 \pm 0.001 \\
*_{+}\end{array}$ & $\begin{array}{l}0.67 \pm 0.031 \\
* *+\end{array}$ & $\begin{array}{l}0.41 \pm 0.012 \\
* *+\end{array}$ & $\begin{array}{l}0.12+0.005 \\
*_{+}\end{array}$ & $\begin{array}{l}0.27 \pm 0.007 \\
*_{+}\end{array}$ \\
\hline & Endosteal area & $\begin{array}{l}0.55+0.015 \\
*++\end{array}$ & $\begin{array}{l}0.48 \pm 0.011 \\
*_{+}\end{array}$ & $\begin{array}{l}0.53 \pm 0.019 \\
*+++\end{array}$ & $\begin{array}{l}0.40 \pm 0.014 \\
*_{+}\end{array}$ & $\begin{array}{l}0.56 \pm 0.017 \\
* *+\end{array}$ & $\begin{array}{l}0.50 \pm 0.014 \\
* *+\end{array}$ & $\begin{array}{l}0.50 \pm 0.016 \\
* *+\end{array}$ & $\begin{array}{l}0.59 \pm 0.022 \\
* *+++\end{array}$ \\
\hline & Intermediary area & $\begin{array}{l}0.53+0.017 \\
* * *++\end{array}$ & $\begin{array}{l}0.55 \pm 0.019 \\
* * *+++\end{array}$ & $\begin{array}{l}0.48 \pm 0.014 \\
*_{+}\end{array}$ & $\begin{array}{l}0.43+0.011 \\
*+++\end{array}$ & $\begin{array}{l}0.60 \pm 0.028 \\
*_{+}\end{array}$ & $\begin{array}{l}0.54 \pm 0.018 \\
*+++\end{array}$ & $\begin{array}{l}0.48 \pm 0.012 \\
*_{+}\end{array}$ & $\begin{array}{l}0.60 \pm 0.029 \\
*+++\end{array}$ \\
\hline \multirow[t]{3}{*}{ Distal bone section } & Periosteal area & $\begin{array}{l}0.21 \pm 0.002 \\
* *+\end{array}$ & $\begin{array}{l}0.30 \pm 0.011 \\
* *++\end{array}$ & $\begin{array}{l}0.30 \pm 0.013 \\
* *+\end{array}$ & $\begin{array}{l}0.24 \pm 0.008 \\
* *+\end{array}$ & $\begin{array}{l}0.38 \pm 0.015 \\
* *+\end{array}$ & $\begin{array}{l}0.30 \oplus 0.013 \\
* *+\end{array}$ & $\begin{array}{l}0.07 \pm 0.002 \\
*_{+}\end{array}$ & $\begin{array}{l}0.41 \pm 0.015 \\
*_{+}\end{array}$ \\
\hline & Endosteal area & $\begin{array}{l}0.49 \pm 0.015 \\
* *+++\end{array}$ & $\begin{array}{l}0.55+0.020 \\
* *+++\end{array}$ & $\begin{array}{l}0.49 \pm 0.016 \\
*+++\end{array}$ & $\begin{array}{l}0.41 \pm 0.014 \\
*++\end{array}$ & $\begin{array}{l}0.49 \pm 0.013 \\
* * *+\end{array}$ & $\begin{array}{l}0.49 \pm 0.023 \\
* * *+\end{array}$ & $\begin{array}{l}0.47 \pm 0.021 \\
* *+\end{array}$ & $\begin{array}{l}0.57 \pm 0.022 \\
* *+\end{array}$ \\
\hline & Intermediary area & $\begin{array}{c}0.45 \pm 0.016 \\
*_{+}\end{array}$ & $\begin{array}{l}0.55+0.021 \\
*_{+}\end{array}$ & $\begin{array}{l}0.42 \pm 0.015 \\
* * *+\end{array}$ & $\begin{array}{l}0.40 \pm 0.014 \\
* * *+\end{array}$ & $\begin{array}{c}0.64 \pm 0.031 \\
*_{+}\end{array}$ & $\begin{array}{c}0.52+0.017 \\
*_{+}\end{array}$ & $\begin{array}{l}0.36 \pm 0.013 \\
*\end{array}$ & $\begin{array}{c}0.59 \pm 0.023 \\
*+++\end{array}$ \\
\hline $\begin{array}{l}\text { Median connective tissue } \\
\text { extension }\end{array}$ & Periosteal area & $\begin{array}{c}0.35 \pm 0.011 \\
* *+\end{array}$ & $\begin{array}{c}0.31 \pm 0.014 \\
* *+\end{array}$ & $\begin{array}{c}0.22+0.005 \\
*_{+}\end{array}$ & $\begin{array}{c}0.13+0.003 \\
*++\end{array}$ & $\begin{array}{c}0.51 \pm 0.017 \\
* *+\end{array}$ & $\begin{array}{c}0.41 \pm 0.019 \\
* *+\end{array}$ & $\begin{array}{c}0.21 \pm 0.005 \\
* *+\end{array}$ & $\begin{array}{c}0.28+0.011 \\
* *+\end{array}$ \\
\hline
\end{tabular}




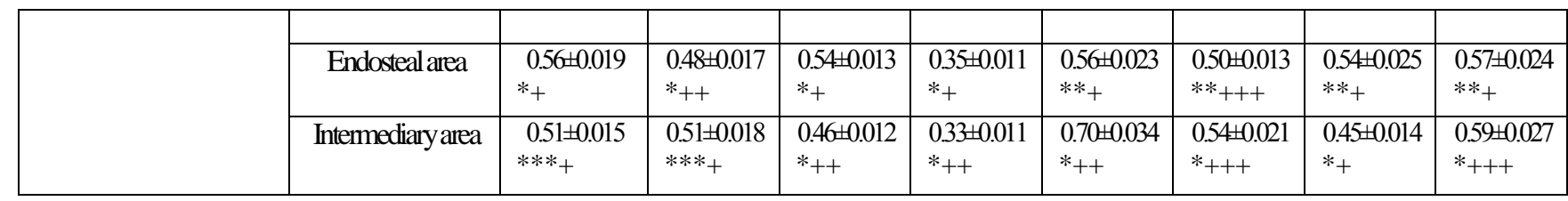

$*_{-}$at $\mathrm{p}<0.01$ - differences are significant in comparison with animals from the other test series;

$* *$ - at $\mathrm{p}<0.05$ - differences are significant in comparison with animals from the other test series;

$* * *$ - at $\mathrm{p} \geq 0.05$ - differences are insignificant in comparison with animals from the other test series;

+- at $\mathrm{p}<0.01-$ differences are significant in comparison with the period of distraction;

++- at $\mathrm{p}<0.05$ - differences are significant in comparison with the period of distraction;

+++- at $\mathrm{p} \geq 0.05$ - differences are insignificant in comparison with the period of distraction.

A month after the external fixation removal, the OD parameters in Series II were close to Series I at the level of fractured bone fragments on the lateral and posterior surfaces. On the medial and anterior surfaces, the parameters remained lower by $10-17 \%$ than in the fractured bone fragments in Series I (Table 3).

Animals from both Series had a decrease in the OD in the periosteal and endosteal areas and an increase in the intermediary area, which indicated the development of the organ-specific structure in the regenerated area of the bone during this period. At the same time, the OD in Series II decreased by $6-8 \%$ in the intermediary area in the projection of the bone sections and by $20-40 \%$ in the projection of the median connective tissue extension. In the periosteal area, in the distal bone section and in the projection of the connective tissue extension on the medial surface, the parameters remained elevated in comparison with Series I by 1.4-1.7 times.

Table 3. The optical density in different areas of the distraction regenerate of the tibia 30 days after the external fixation removal

\begin{tabular}{|c|c|c|c|c|c|c|c|c|c|}
\hline \multirow{4}{*}{\multicolumn{2}{|c|}{ Regenerate areas }} & \multicolumn{8}{|c|}{$\mathrm{OD}(\mathrm{M} \pm \mathrm{m})$} \\
\hline & & \multicolumn{8}{|c|}{ Regenerate region (in regards to the studied surface) } \\
\hline & & \multicolumn{2}{|c|}{ Lateral } & \multicolumn{2}{|c|}{ Medial } & \multicolumn{2}{|c|}{ Anterior } & \multicolumn{2}{|c|}{ Posterior } \\
\hline & & I & I & I & I & I & I & I & I \\
\hline \multicolumn{2}{|c|}{ Proximal fractured bone fragment } & $\begin{array}{c}0.62+0.025 \\
* * *+++\end{array}$ & $\begin{array}{r}0.62+0.028 \\
* * *+++\end{array}$ & $\begin{array}{c}0.63+0.025 \\
*_{+++}\end{array}$ & $\begin{array}{c}0.47 \pm 0.018 \\
*+++\end{array}$ & $\begin{array}{c}0.70 \oplus 0.033 \\
*+++\end{array}$ & $\begin{array}{c}0.56 \pm 0.023 \\
*++\end{array}$ & $\begin{array}{c}0.66 \pm 0.029 \\
* *+++\end{array}$ & $\begin{array}{c}0.61 \pm 0.027 \\
* *+++\end{array}$ \\
\hline \multicolumn{2}{|c|}{ Distal fractured bone fragment } & $\begin{array}{l}0.56 \pm 0.026 \\
* * *++\end{array}$ & $\begin{array}{l}0.56 \pm 0.017 \\
* * *++\end{array}$ & $\begin{array}{l}0.61 \pm 0.028 \\
*_{+++}\end{array}$ & $\begin{array}{l}0.55 \pm 0.021 \\
*_{+}\end{array}$ & $\begin{array}{l}0.69 \pm 0.031 \\
*+++\end{array}$ & $\begin{array}{l}0.58 \pm 0.027 \\
*+++\end{array}$ & $\begin{array}{l}0.60 \pm 0.023 \\
* *+++\end{array}$ & $\begin{array}{l}0.57 \pm 0.024 \\
* *++\end{array}$ \\
\hline \multirow[t]{3}{*}{$\begin{array}{l}\text { Proximal } \\
\text { bone section }\end{array}$} & Periosteal area & $\begin{array}{l}0.37 \pm 0.011^{*} \\
++\end{array}$ & $\begin{array}{l}0.19 \pm 0.007 \\
*++\end{array}$ & $\begin{array}{l}0.19 \pm 0.006 \\
*_{+}\end{array}$ & $\begin{array}{l}0.09 \pm 0.003 \\
*++\end{array}$ & $\begin{array}{l}0.35 \pm 0.012 \\
*+\end{array}$ & $\begin{array}{l}0.22+0.008 \\
*+\end{array}$ & $\begin{array}{l}0.27 \pm 0.010 \\
* * *+\end{array}$ & $\begin{array}{l}0.23 \pm 0.006 \\
* * *+\end{array}$ \\
\hline & Endosteal area & $\begin{array}{l}0.58 \pm 0.026 \\
* *+++\end{array}$ & $\begin{array}{l}0.52 \pm 0.021 \\
* *_{+}\end{array}$ & $\begin{array}{l}0.48 \pm 0.019 \\
*_{+}\end{array}$ & $\begin{array}{l}0.36 \pm 0.011 \\
*_{+}\end{array}$ & $\begin{array}{l}0.54 \pm 0.018 \\
*_{++}\end{array}$ & $\begin{array}{l}0.47 \pm 0.011 \\
*++\end{array}$ & $\begin{array}{l}0.50 \oplus 0.013 \\
* * *+++\end{array}$ & $\begin{array}{l}0.55+0.012 \\
* * *++\end{array}$ \\
\hline & Intermediary area & $\begin{array}{l}0.57 \pm 0.025 \\
* *++\end{array}$ & $\begin{array}{l}0.49 \pm 0.023 \\
* *+\end{array}$ & $\begin{array}{l}0.50 \pm 0.022 \\
* * *+++\end{array}$ & $\begin{array}{l}0.48 \pm 0.020 \\
* * *++\end{array}$ & $\begin{array}{l}0.68 \pm 0.013 \\
* * *+\end{array}$ & $\begin{array}{l}0.45+0.010 \\
* * *+\end{array}$ & $\begin{array}{l}0.58 \pm 0.019 \\
* *_{+}\end{array}$ & $\begin{array}{l}0.53 \pm 0.015 \\
* *+\end{array}$ \\
\hline \multirow[t]{3}{*}{$\begin{array}{l}\text { Distal bone } \\
\text { section }\end{array}$} & Periosteal area & $\begin{array}{l}0.15 \pm 0.006 \\
*\end{array}$ & $\begin{array}{l}0.26 \pm 0.011 \\
*\end{array}$ & $\begin{array}{l}0.1 \pm 0.004 \\
*\end{array}$ & $\begin{array}{l}0.30 \pm 0.003 \\
*\end{array}$ & $\begin{array}{l}0.50 \pm 0.017 \\
*\end{array}$ & $\begin{array}{l}0.22 \pm 0.013 \\
*\end{array}$ & $\begin{array}{l}0.21 \pm 0.009 \\
* *\end{array}$ & $\begin{array}{l}0.29 \pm 0.011 \\
* *\end{array}$ \\
\hline & Endosteal area & $\begin{array}{l}0.54 \pm 0.021^{*} \\
* *\end{array}$ & $\begin{array}{l}0.51 \pm 0.019 \\
* * *\end{array}$ & $\begin{array}{l}0.53 \pm 0.024 \\
*\end{array}$ & $\begin{array}{l}0.35 \pm 0.015 \\
*\end{array}$ & $\begin{array}{l}0.54 \pm 0.013 \\
* * *\end{array}$ & $\begin{array}{l}0.57 \pm 0.017 \\
* * *\end{array}$ & $\begin{array}{l}0.53 \pm 0.015 \\
* * *\end{array}$ & $\begin{array}{l}0.55 \pm 0.017 \\
* * *\end{array}$ \\
\hline & Intermediaryarea & $\begin{array}{c}0.49 \pm 0.021 \\
* * *\end{array}$ & $\begin{array}{l}0.49 \pm 0.019 \\
* * *\end{array}$ & $\begin{array}{l}0.46 \pm 0.013 \\
* *\end{array}$ & $\begin{array}{c}0.41 \pm 0.009 \\
* *\end{array}$ & $\begin{array}{c}0.68 \pm 0.027 \\
*\end{array}$ & $\begin{array}{c}0.53+0.013 \\
*\end{array}$ & $\begin{array}{l}0.54 \pm 0.019 \\
* *\end{array}$ & $\begin{array}{c}0.50 \pm 0.012 \\
* *\end{array}$ \\
\hline $\begin{array}{l}\text { Median } \\
\text { connective tissue } \\
\text { extension }\end{array}$ & Periosteal area & $0.30 \pm 0.011$ & $0.27 \pm 0.006$ & $0.26 \pm 0.004$ & $0.36 \pm 0.001$ & $0.28 \pm 0.006$ & $0.21 \pm 0.004$ & $0.26 \pm 0.008$ & $0.25 \pm 0.003$ \\
\hline
\end{tabular}




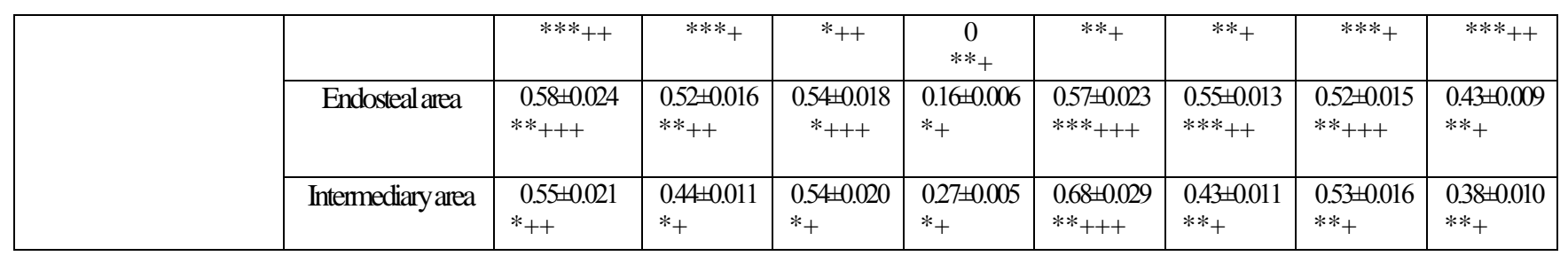

$*-$ at $\mathrm{p}<0.01$ - differences are significant in comparison with animals from the other test series;

$* *$ - at $\mathrm{p}<0.05$ - differences are significant in comparison with animals from the other test series;

$* * *$ - at $\mathrm{p} \geq 0.05$ - differences are insignificant in comparison with animals from the other test series;

+- at $\mathrm{p}<0.01-$ differences are significant in comparison with the period of fixation;

++- at $\mathrm{p}<0.05-$ differences are significant in comparison with the period of fixation;

+++- at $\mathrm{p} \geq 0.05$ - differences are insignificant in comparison with the period of fixation.

The obtained results showed that oblique osteotomy contributes to better mineralization of bone sections and the median connective tissue extension during the periods of distraction and fixation in comparison with flexion osteoclasis, expect from the studied areas on the median surface. This could be associated with the formation of the operative access in this area and higher disturbance of the blood circulation in the surrounding tissues. In Series I of the experimental study, lower mineralization of the regenerate structures was observed in the projection of the anterior surface because of the higher traumaticity of flexion osteoclasis.

Xia Lan et al. [12] suggest that a good outcome after oblique osteotomy for the lengthening of a limb is associated with a major area of the contact between the bone fragments and their better stability. Other authors [13] highlight that oblique osteotomy is rarely used by surgeons. One of the reasons is the difficulty in providing the required stiffness of the external fixation on a short bone fragment. Still, there are published data on the experience of this technique application with a positive outcome $[14 ; 15]$. In the present study, the authors obtained better results at the stages of distraction and fixation in the series after oblique osteotomy (Series II), which allowed for the removal of the external fixation 14 days after the installation because of the restoration of the supporting ability in the regenerated area of the diaphysis.

The parameters of the OD in both Series after the removal of the external fixation in the intermediary and endosteal areas of the regenerate were not less than $0.5 \mathrm{CU}$ minimum in two projections, which can be a criterion for the evaluation of the possibility of the external fixation removal. At the same time, the minimal values of OD in the projection of the other two surfaces should not be below $0.33 \mathrm{CU}$.

\section{CONCLUSIONS.}

Automatic extraction of the lower leg at the rate of $3 \mathrm{~mm} /$ day after the bone damage with oblique osteotomy contributes to more active osteogenesis during the period of distraction, which leads to early substitution of the connective tissue extension with bone tissue and restores the supporting ability already 14 days after the removal of the external fixation, which reduces the period of external fixation by $16 \%$ in comparison with flexion osteoclasis. At the same time, 30 days after the removal of the external fixation, the signs of incomplete organ-specific transformation of the newly formed area of the diaphysis remain. When the parameters of the OD 
were more than $0.5 \mathrm{CU}$ in the distraction regenerate in the intermediary and endosteal areas on two and more surfaces and not less than $0.3 \mathrm{CU}$ in the rest areas, the regenerate acquired the supporting ability. The obtained results can be used as the criteria for the removal of the external fixation.

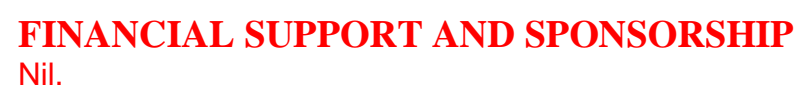

The authors declare no conflict of interest

SUPPLEMENTARY DATA (DOI)

\section{REFERENCES}

1. Gorbach E.N., Stepanov M.A. Features of bone morphogenesis in tibia elongation by transosseous distraction osteosynthesis at increased daily rate [Osobennosti morfogeneza kostnoi tkani pri udlinenii goleni metodom chreskostnogo distraktsionnogo osteosinteza pri povyshennom sutochnom tempe ]. Morphology - Morfologiia, 2015, vol. 147, no. 2, pp. 69-74..

2. Popkov A.V., 1 Popkov D.A., 1 Kononovich N.A. et al. New technology of limb lengthening using a robotic distractor (a preclinical trial) [Novaia tekhnologiia udlineniia konechnosti robotizirovannym distraktorom (doklinicheskoe ispytanie)]. International journal of applied and fundamental research - Mezhdunarodnyi zhurnal prikladnykh i fundamental'nykh issledovanii, 2016, vol. 1, no. 9, pp. 74-77.

3. Sokolovsky O.A., Serduchenko S.N., Brodko G.A. et al. Equalizing of lower extremities length historical viewpoints and modern trends [Uravnivanie dliny nizhnikh konechnostei - istoricheskie rakursy i sovremennye tendentsii]. Medical news - Meditsinskie novosti, 2011, no. 7, pp. 11-19.

4. Sakhno N.V. Body reactivity depending on the area of fracture of tubular bones [Reaktivnost' organizma $\mathrm{v}$ zavisimosti ot ploshchadi pereloma trubchatykh kostei]. Veterinary pathology Veterinarnaia patologiia, 2008, no. 2, pp. 97-101.

5. Kiselev V.Ia., Mel'nichenko P.A., Izmailov T.B. Closed monolocal distraction osteosynthesis is a current direction in rehabilitation in the treatment of diafysical tibia defects of the tibia [Zakrytyi monolokal'nyi distraktsionnyi osteosintez - aktual'noe napravlenie v reabilitatsii pri lechenii diafizarnykh defektov bol'shebertsovoi kosti goleni]. Allergology and immunology - Allergologiia $i$ immunologiia, 2012, vol. 13, no. 4, p. 330.

6. Silant'eva T.A., Chirkova A.M., Erofeev S.A. The histomorphometric characteristic of distraction osteogenesis activity for different ways of leg bone integrity disturbance (experimental study) [Gistomorfometricheskaia kharakteristika aktivnosti distraktsionnogo osteogeneza pri razlichnykh sposobakh narusheniia tselostnosti kostei goleni (eksperimental'noe issledovanie)]. Genij Ortopedii - Genii Ortopedii, 2003, no. 3, pp. 120-125.

7. Gorevanov E.A., Muradisinov S.O., Kolchev O.V. et al. The roentgenological dynamics of bone 
tissue regeneration for monosegmental bifocal leg lengthening in children and adolescents with congenital shortening of the lower limbs [Rentgenologicheskaia dinamika regeneratsii kostnoi tkani pri monosegmentarnom bilokal'nom udlinenii goleni u detei i podrostkov s vrozhdennym ukorocheniem nizhnikh konechnostei]. Genij ortopedii - Genii Ortopedii, 2003, no 4, pp. 15-20.

8. D'iachkova G.V., Klimov O.V., Aranovich A.M. et al. New possibilities of studying a regenerated bone by radiography data [Novye vozmozhnosti izucheniia distraktsionnogo regenerata po dannym rentgenografii]. Genij ortopedii - Genii Ortopedii, 2015, no 3, pp. 60-66.

9. Aranovich A.M., Djachkova G.V., Klimov O.V. et al. Digital analysis techniques of distraction regenerate radiological image in tibial lengthening of achobdroplasia patient [Metodiki tsifrovogo analiza rentgenologicheskogo izobrazheniia distraktsionnogo regenerata pri udlinenii golenei $\mathrm{u}$ bol'nykh akhondroplaziei]. Fundamental Research - Fundamental'nye issledovaniia, 2015, no 1-6, pp. 1115-1119.

10. Klimov O.V., Liashchenko A.N., Ban'shchikov A.S. Computer program "Hi-scene" for computer analysis, evaluation and documentation of data of beam methods of research and any electronic images, as well as carrying out on the basis of obtained data of pre-operational modeling: Russian Patent. [Programma EVM «Hi - scene» dlia provedeniia komp'iuternogo analiza, otsenki i dokumentatsii dannykh luchevykh metodov issledovaniia i liubykh elektronnykh izobrazhenii, a takzhe provedeniia na osnovanii poluchennykh dannykh predoperatsionnogo modelirovaniia: Patent Rossii], № 2014611777, 2014.

11. Gaidyshev I.P. Solve scientific and engineering problems with Excel, VBA and C++ [Reshenie nauchnykh i inzhenernykh zadach sredstvami Excel, VBA i C++]. St. Petersburg, BKhV-Peterburg, 2004, 512 p.

12. Lan X., Zhang L., Tang P. et al. S-osteotomy with lengthening and then nailing compared with traditional Ilizarov method. International Orthopaedics, 2013, vol. 37, no 10, pp. 1995-2000, doi 10.1007/s00264-013-1962-x.

13. Kulesh P.N., Solomin L.N. Correction of leg shape by aesthetic indications (literature review). [Korrektsiia formy nog po esteticheskim pokazaniiam (obzor literatury)] Genij ortopedii - Genii Ortopedii, 2013, no 2, pp. 117-123.

14. Barinov A.S., Vorob'ev A.A., Zaitsev S.S. Cosmetic aspects of operative correction of dysplastic varus deformations of lower limbs. [Kosmeticheskie aspekty operativnoi korrektsii displasticheskikh varusnykh deformatsii nizhnikh konechnostei] Clinical Medicine - Klinicheskaya Meditsina, 2010, no 4, pp. 57-60.

15. Al-Saati M., Magnussen R.A., Lustig S. et al. Distraction osteogenesis using a longitudinal corticotomy. International Orthopaedics, 2012, vol. 36, no 5, pp.1073-1077, doi 10.1007/s00264011-1383-7. 